\title{
Comparison of an elemental and polymeric enteral diet in patients with normal gastrointestinal function
}

\author{
B J M JONES, R LEES, J ANDREWS, P FROST, and D B A SILK
}

From the Departments of Gastroenterology, Clinical Chemistry and Dietetics, Central Middlesex Hospital, London

SUMMARY In a prospective controlled clinical trial, 70 patients with normal gastrointestinal function were randomised to receive either an elemental diet based on Vivonex HN or an isonitrogenous isocalorie polymeric diet based on Clinifeed 400 , administered by continuous 24 hour nasogastric infusion. The two groups of patients were well matched for age, sex, diagnosis, prior starvation, duration of feeding, initial nutritional status, and metabolic status. Nitrogen losses were significantly less on the polymeric feed, despite similar intakes. Serum transferrin rose significantly $(1 \cdot 85 \pm 0 \cdot 2$ to $2 \cdot 30 \pm 0.2 \mathrm{~g} / \mathrm{l}, \mathrm{p}<0.05)$ only in the Clinifeed group, but nutritional parameters were otherwise maintained in both groups. The incidence of diarrhoea (Vivonex, $23.5 \%$; Clinifeed, $30.6 \%$ ) was not significantly different and was attributable to antibiotics in most cases. Hypokalaemia, which occurred in nearly half the patients, was equally distributed in the two groups, but hypophosphataemia occurred more often in the Vivonex group $(\mathrm{p}<0 \cdot 05)$. Liver enzyme disturbances were similar in both groups. The present findings, therefore, provide no evidence that chemically defined 'elemental' diets containing free amino acids as their nitrogen source are in any way superior to polymeric diets containing whole protein and fat when administered to patients with normal gastrointestinal function.

One of the major differences between chemically defined 'elemental diets' and standard polymeric liquid diets used for enteral feeding is that elemental diets contain partially or completely hydrolysed protein as their nitrogen source whereas polymeric diets contain undigested protein. Despite the fact that elemental diets are more hypertonic and expensive than polymeric diets, they have been widely used in the clinical setting, not only in patients with impaired gastrointestinal function, but also in those with normal gastrointestinal function, all of whom would appear to be perfectly capable of assimilating whole protein. ${ }^{1}$ In agreement with others $^{2-4}$ we have held the view that this inappropriate usage of 'elemental diets' cannot be supported, as there is very little clinical or experimental data available to substantiate the claims made for them. ${ }^{1}$

We now report the results of a controlled

Received for publication 22 April 1982 prospective clinical trial designed to compare the nutritional efficacy and side-effects of isonitrogenous isocaloric regimes of an elemental diet, Vivonex HN, and a polymeric diet, Clinifeed 400 , administered to a diagnostically heterogeneous group of patients with no clinical evidence of impairment of gastrointestinal function and in whom nasogastric feeding was indicated as the sole source of nutritional intake.

\section{Methods}

PATIENTS, MATERIAL, AND DIETARY REGIMES Included in the study were 70 patients with no clinical evidence of impaired luminal nutrient digestion or absorptive capacity and in whom it was considered that nasogastric feeding rather than parenteral feeding was indicated as the sole source of nutritional support in order to maintain or improve nutritional status. Patients were referred from all specialties throughout the hospital and were considered for enteral nutritional support only if 
they were considered unlikely to be able to return to normal oral nutrition within one week. The patients did not have to satisfy criteria for the presence of impaired nutritional status.

Patients in whom fluid restriction was indicated for example, those with cardiac, respiratory or renal failure, or inappropriate secretion of antidiuretic hormone (ADH), diabetics, and those with recent diarrhoea, vomiting or regurgitation of gastric contents were all excluded from the study. Finally, a small number of patients known to have nitrogen excretion in excess of $14.4 \mathrm{~g} /$ day before the study were excluded.

The trial was conducted over a 12-month period (April 1979-April 1980) and the 70 patients constituted $36 \%$ of 185 patients receiving nutritional support during the same period, $47(24.1 \%)$ of whom received total parenteral nutrition. The remaining $78(40 \%)$ were treated with various enteral regimes outside the trial.

Having satisfied inclusion criteria, 70 patients were randomised by the drawing of numbered envelopes containing cards allocated by random numbers to one of two diets, Vivonex HN (Eaton Laboratories Ltd; 34 patients) or Clinifeed 400 (Roussel Laboratories Ltd; 36 patients).

Both regimes (Table 1) contained $4.8 \mathrm{~g}$ nitrogen/1 and a non-protein calorie to nitrogen ratio of 200 $\mathrm{Kcal} / \mathrm{g}$ nitrogen achieved by supplementing the basic diets with a glucose polymer energy source (Caloreen, Roussel Laboratories Ltd). Starter regimes were used for both groups starting with 21 of half strength feed on day 1 and progressing to 21 of full strength by day 4 .

On days $1-3$, nitrogen losses were estimated from urinary nitrogen according to the method described by Lee and Hartley ${ }^{5}$ and validated for patients with normal gastrointestinal function. ${ }^{6}$ This method

Table 1 Composition of diets

\begin{tabular}{|c|c|c|}
\hline Constituent per litre & Vivonex $H N$ & Clinifeed 400 \\
\hline Free amino acids (g/l) & 31 (4.8 g nitrogen) & - \\
\hline Whole protein $(\mathrm{g} / \mathrm{l})$ & - & 30 (4.8 g nitrogen $)$ \\
\hline Total carbohydrate $(\mathrm{g} / \mathrm{l})$ & $240 \dagger$ & $160 \dagger$ \\
\hline Lactose $(\mathrm{g} / \mathrm{l})$ & - & $19 \cdot 5$ \\
\hline Fat $(g / 1)$ & 0.63 & $26 \cdot 8$ \\
\hline Potassium (mmol/l) & 13 & 25 \\
\hline $\operatorname{Zinc}(\mathrm{mg} / \mathrm{l})$ & $3 \cdot 0$ & $6 \cdot 0$ \\
\hline Phosphate (mg/l) & 190 & 460 \\
\hline Folic acid $(\mu \mathrm{g} / \mathrm{l})$ & 24 & 300 \\
\hline \multicolumn{3}{|l|}{ Non-protein calories* } \\
\hline $\mathrm{g} \alpha$-amino nitrogen & 200:1 & 200:1 \\
\hline Osmolality $(\mathrm{mosm} / \mathrm{kg})$ & 690 & 395 \\
\hline Volume administered (1) & $2-3$ & $2-3$ \\
\hline
\end{tabular}

includes a standard correction factor for faecal and skin losses, which could not be estimated in our patients because of practical problems, such as faecal collection in the unconscious and the logistic problem of assaying large numbers of stool collections in a busy clinical chemistry department.

Patients with nitrogen losses equal to or less than $9.6 \mathrm{~g}$ nitrogen/day, calculated as above, were prescribed 21 full strength diet supplying $9.6 \mathrm{~g}$ nitrogen and $1920 \mathrm{Kcal}$ on day 4 and thereafter, unless further daily nitrogen balance studies indicated greater losses. In this case, patients were transferred to 31 full strength feed, the regime also instituted in those patients in whom there were nitrogen losses of between 9.6 and $14.4 \mathrm{~g}$ nitrogen/ day as detected during the first four days of treatment. By using this flexible approach, nitrogen input could be adjusted to match, or just exceed, calculated nitrogen losses.

Feeding was continued until no longer clinically indicated or until the patient was ready to start oral feeding.

\section{TECHNIQUE OF ADMINISTRATION}

The enteric diets were administered by continuous 24 hour gravity controlled infusion using a standard giving set and a $1 \mathrm{~mm}$ internal diameter nasogastric tube (Clinifeeding Systems I and II, Roussel Laboratories Ltd) and standard $500 \mathrm{ml}$ glass Winchester (DHSS 4168). ${ }^{7}$ Feeds were prepared 24 hours in advance in the hospital diet kitchen using sterile water and refrigerated at $4^{\circ} \mathrm{C}$ before use.

\section{NUTRITIONAL STATUS}

Nutritional status of the patients was assessed before randomisation and at weekly intervals thereafter. Anthropometric assessment included measurement of triceps skinfold thickness, midarm circumference, and midarm muscle circumference. ${ }^{8}$ Biochemical assessment included management of serum albumin, ${ }^{9}$ transferrin, ${ }^{9}$ thyroid binding pre-albumin (TBPA),${ }^{9}$ potassium, zinc, and phosphate. Haematological parameters assessed were lymphocyte count, serum $B_{12}$, serum folate, and red cell folate. Delayed hypersensitivity was assessed as an indication of cellular immunity by using the recall antigens PPD (Evans Medical Ltd), Candida albicans (Bencard Ltd), and streptodornase-streptokinase (Lederle Laboratories). These tests were judged to be impaired when more than one of the antigens failed to induce induration of greater than 5 $\mathrm{mm} 48$ hours after intradermal injection. ${ }^{10}$

Twenty-four hour urinary excretion of urea and creatinine was measured daily. Urinary urea nitrogen excretion reflects both muscle mass and the degree of catabolism, ${ }^{11}$ whereas urine creatinine is 
related more closely to muscle mass alone. ${ }^{12}$ The ratio of urinary urea nitrogen:urinary creatinine excretion was, therefore, used to obtain a clearer assessment of metabolic status independent of differences in muscle mass.

\section{STATISTICS}

Advice concerning the statistical analysis of the trial data was sought from the Department of Medical Statistics, Charing Cross Hospital, London. Paired and unpaired Student's $t$ tests and $\chi^{2}$ tests were performed as appropriate.

\section{Results}

\section{CLINICAL DiAgNosis (Table 2)}

The patients in both the Vivonex and Clinifeed groups were well matched for age, sex, race, and duration of prior starvation (Table 2). The two groups were also comparable with respect to underlying clinical diagnosis. Neurological patients (including those with head injuries and intracranial haemorrhage) and those with neurological disorders affecting either conscious level or swallowing reflexes comprised the majority of each group (Vivonex, 59\%; Clin.ieed, 66.6\%). The numbers in each group with surgical diagnoses were similar, although there were more postoperative cases in the Vivonex group. The medical categories included patients with anorexia nervosa, meningitis, tuberculosis, and respiratory failure requiring ventilatory support. Sepsis, defined as infection giving rise to fever, tachycardia, and leucocytosis on

Table 2 Comparability of two treatment groups

\begin{tabular}{lll}
\hline & $\begin{array}{l}\text { Vivonex } \\
(n=34)\end{array}$ & $\begin{array}{l}\text { Clinifeed } \\
(n=36)\end{array}$ \\
\hline $\begin{array}{ll}\text { Age (mean } \pm \text { SEM) (yr) } \\
\text { Sex }\end{array} \quad 55 \cdot 1 \pm 3 \cdot 1$ & $56 \cdot 1 \pm 3 \cdot 1$ \\
$\quad$ Male & 20 & 23 \\
$\quad$ Female & 14 & 13 \\
$\begin{array}{l}\text { Race } \\
\quad \text { Caucasian }\end{array}$ & 31 & 34 \\
$\quad$ Non-Caucasian & 3 & 2 \\
$\begin{array}{l}\text { Diagnostic category } \\
\quad \text { Neurosurgical }\end{array}$ & 11 & 12 \\
$\quad \begin{array}{l}\text { Neurological } \\
\text { Surgical }\end{array} \quad 9$ & 12 \\
$\quad \begin{array}{l}\text { Preop } \\
\quad \text { Postop }\end{array}$ & 3 & 7 \\
$\quad \begin{array}{l}\text { Medical } \\
\quad \text { days before trial }\end{array}$ & 7 & 2 \\
$\quad \begin{array}{l}\text { Mean duration of prior starvation } \\
\text { (days) (mean } \pm \text { SEM) }\end{array}$ & 4 & 3 \\
\begin{tabular}{l} 
Presence of infection \\
\hline
\end{tabular} & $16(47 \%)$ & $17(47 \%)$ \\
\hline
\end{tabular}

more than one day, either as the primary or secondary diagnosis, was distributed evenly between the two groups. The number of patients starved for longer than one week was also similar in each group.

NUTRITIONAL STATUS (Table 3 )

Patients in the two treatment groups had similar nutritional status on entry to the study, anthropometric data indicating only a moderate degree of muscle mass depletion as indicated by midarm muscle circumference values, but considerable depletion of body fat reserves as indicated by triceps skinfold thickness values. ${ }^{13}$ Moreover, there was no significant difference in muscle mass as inferred from daily urinary creatinine excretion results ${ }^{12}$ (Vivonex, 8.2 $\pm 0.8 \mathrm{mmol} / \mathrm{d}$; Clinifeed, 9.0 $\pm 1 \cdot 0$ $\mathrm{mmol} / \mathrm{d})$. It was not possible to measure the patients' height because of the nature of their illnesses and therefore the 'creatinine height index' could not be calculated. For similar reasons, weights have not been included, as so few patients were physically capable of being weighed and thus data would have been unrepresentative of the group as a whole.

The metabolic status of each complete group initially, as determined by the ratio of urinary urea nitrogen to urinary creatinine, did not differ significantly (Vivonex, $1.0 \pm 0.08$; Clinifeed, $1 \cdot 28 \pm 0 \cdot 25$ ) on entry to the study.

\section{DURATION OF FEEDING}

The mean duration of feeding (Vivonex, 14.3 $\pm 1 \cdot 5$ days; Clinifeed, $15 \cdot 2 \pm 2 \cdot 0$ days) was similar, as was

Table 3 Nutritional status on entry to study

\begin{tabular}{|c|c|c|}
\hline & $\begin{array}{l}\text { Vivonex } \\
\text { group }\end{array}$ & $\begin{array}{l}\text { Clinifeed } \\
\text { group }\end{array}$ \\
\hline \multicolumn{3}{|l|}{ Triceps skin fold (TSF) } \\
\hline Male $(7 \cdot 5-11 \cdot 3 \mathrm{~mm})^{*}$ & $7 \cdot 5 \pm 0 \cdot 7$ & $7 \cdot 2 \pm 0 \cdot 7$ \\
\hline Female $(9.9-14.9 \mathrm{~mm})^{*}$ & $10 \cdot 9 \pm 1 \cdot 5$ & $11 \cdot 3 \pm 1 \cdot 2$ \\
\hline \multicolumn{3}{|l|}{ Midarm circumference (MAC) } \\
\hline Male $(17 \cdot 6-26 \cdot 3 \mathrm{~cm})^{*}$ & $26 \cdot 3 \pm 0 \cdot 9$ & $24 \cdot 4 \pm 1 \cdot 0$ \\
\hline Female $(17 \cdot 1-25 \cdot 7 \mathrm{~cm})^{*}$ & $22 \cdot 5 \pm 2 \cdot 0$ & $24 \cdot 7 \pm 1 \cdot 5$ \\
\hline \multicolumn{3}{|c|}{ Midarm muscle circumference (MAMC) $\dagger$} \\
\hline Male $(15 \cdot 2-22 \cdot 8 \mathrm{~cm})^{*}$ & $24 \cdot 2 \pm 0 \cdot 7$ & $22 \cdot 6 \pm 0 \cdot 6$ \\
\hline Female $(13.9-20.9 \mathrm{~cm})^{*}$ & $20 \cdot 6 \pm 0.9$ & $21 \cdot 1 \pm 1 \cdot 2$ \\
\hline Albumin $g / 1(35 \cdot 0) \ddagger$ & $35 \cdot 5 \pm 1 \cdot 0$ & $35 \cdot 8 \pm 1 \cdot 0$ \\
\hline Transferrin $\mathrm{g} / \mathrm{l}(2 \cdot 0) \ddagger$ & $1 \cdot 97 \pm 0 \cdot 12$ & $1 \cdot 95 \pm 0 \cdot 1$ \\
\hline Lymphocyte count $\times 10^{6} / 1(1500) \ddagger$ & $1450 \pm 120$ & $1600 \pm 120$ \\
\hline Impaired skin tests (\% patients) & $78 \%$ & $83 \cdot 3 \%$ \\
\hline
\end{tabular}

* Values in parentheses represent $60-90 \%$ of adult reference values. ${ }^{8}$

+ MAMC $=$ MAC $-(\pi \times$ TSF $)$.

$\ddagger$ Lower limit of normal.

(All values are means \pm SEM.) 
the number of days on which the higher nitrogen regime was administered (Vivonex, $4 \cdot 1 \pm 1 \cdot 1$ days; Clinifeed, $4 \cdot 5 \pm 1 \cdot 6$ days).

There was, however, a wide range of feed duration in each group (Vivonex, one to 35 days; Clinifeed, two to 60 days) but 27 patients on Vivonex and 25 on Clinifeed were fed for longer than one week.

The reasons for termination of feeding are shown in Table 4. Twice as many patients on Clinifeed made successful return to normal nutrition $(p<0.02)$. If, however, the number of patients successfully completing a course of elective preoperative feeding is included with those returning to normal nutrition, the difference between the two treatment groups is no longer significant.

\section{EFFECT OF NUTRITIONAL SUPPORT ON}

\section{NUTRITIONAL STATUS}

The effect of enteral nutrition on nutritional status and nitrogen balance was compared only in those patients fed for more than seven days with nitrogen losses not exceeding $14.4 \mathrm{~g}$ nitrogen per day as shown in Tables 5 and 6 . There were no significant changes in anthropometric parameters within either group except for pre-albumin (thyroid binding pre-albumin) which rose significantly in both groups $(p<0.001)$ and transferrin which increased only in the Clinifeed group $(p<0.05)$. The rise in thyroid
Table 4 End points of trial

\begin{tabular}{lll}
\hline & $\begin{array}{l}\text { Vivonex } \\
\text { group }\end{array}$ & $\begin{array}{l}\text { Clinifeed } \\
\text { group }\end{array}$ \\
\hline 1 Returned to normal oral feeding & 11 & 22 \\
2 Elective preoperative feeding & & \\
$\quad$ terminated by operation & 5 & 3 \\
3 Transfer to other hospitals & 2 & 3 \\
4 Complication of enteral feeding & 4 & 3 \\
$\quad$ necessitating cessation of feeding & 6 & 2 \\
5 Deterioration in clinical condition & 6 & 3 \\
\hline Death & 6 & \\
\hline
\end{tabular}

binding pre-albumin occurred independently of nitrogen balance and changes in albumin and transferrin, this reflecting the known sensitivity of this test to refeeding. ${ }^{9}$

No statistically significant rises in lymphocyte counts occurred in either treatment group. There was a high incidence of negative skin tests at the start of the study in those tested (Vivonex, 25/32 (78\%); Clinifeed, $30 / 36(83.3 \%)$ ) with only small numbers of patients in each group showing an improvement in responsiveness to recall antigens by the end of the study (Vivonex, 9/24 (37.4\%); Clinifeed, 5/24 (21\%)). There was no significant difference between the two treatment groups with respect to the absolute values as shown in Table 5, or to the numbers of patients with improved, maintained, or deteriorating parameters.

Table 5 Nutritional status of patients fed more than seven days and with nitrogen losses $14 \cdot 4 \mathrm{~g} /$ day before and after study

\begin{tabular}{|c|c|c|c|c|}
\hline & \multicolumn{2}{|c|}{$\begin{array}{l}\text { Vivonex group } \\
(n=25)\end{array}$} & \multicolumn{2}{|c|}{$\begin{array}{l}\text { Clinifeed group } \\
(n=21)\end{array}$} \\
\hline & Before & After & Before & After \\
\hline \multicolumn{5}{|l|}{ Triceps skin fold (TSF) } \\
\hline Male $(7 \cdot 5-11 \cdot 3 \mathrm{~mm})^{*}$ & $7 \cdot 4 \pm 1 \cdot 0$ & $7 \cdot 4 \pm 0 \cdot 9$ & $7 \cdot 0 \pm 0 \cdot 8$ & $6 \cdot 3 \pm 0 \cdot 8$ \\
\hline Female $(9 \cdot 9-14.9 \mathrm{~mm})^{*}$ & $11 \cdot 4 \pm 1 \cdot 4$ & $11 \cdot 0 \pm 1 \cdot 2$ & $10 \cdot 9 \pm 2 \cdot 0$ & $10 \cdot 0 \pm 1 \cdot 6$ \\
\hline \multicolumn{5}{|l|}{ Midarm circumference (MAC) } \\
\hline Male $(17 \cdot 6-26 \cdot 3 \mathrm{~cm})^{*}$ & $26 \cdot 5 \pm 1 \cdot 2$ & $26 \cdot 3 \pm 1 \cdot 0$ & $24 \cdot 6 \pm 0 \cdot 3$ & $24 \cdot 6 \pm 0 \cdot 7$ \\
\hline Female $(17 \cdot 1-25 \cdot 7 \mathrm{~cm})^{*}$ & $24 \cdot 9 \pm 1 \cdot 1$ & $24 \cdot 9 \pm 1 \cdot 1$ & $24 \cdot 9 \pm 2 \cdot 0$ & $24 \cdot 7 \pm 0 \cdot 7$ \\
\hline \multicolumn{5}{|c|}{ Midarm muscle circumference (MAMC) $\dagger$} \\
\hline Male $(15 \cdot 2-22 \cdot 8 \mathrm{~cm})^{*}$ & $22 \cdot 7 \pm 1 \cdot 8$ & $23 \cdot 8 \pm 0 \cdot 8$ & $22 \cdot 4 \pm 0 \cdot 8$ & $22 \cdot 5 \pm 0 \cdot 6$ \\
\hline Female $(13.9 \pm 20.9 \mathrm{~cm})^{*}$ & $21 \cdot 3 \pm 0 \cdot 9$ & $21 \cdot 4 \pm 0 \cdot 9$ & $21 \cdot 5 \pm 1 \cdot 6$ & $21 \cdot 5 \pm 1 \cdot 2$ \\
\hline Albumin g/l $(35 \cdot 0) \ddagger$ & $35 \cdot 0 \pm 1 \cdot 1$ & $32 \cdot 1 \pm 1 \cdot 6$ & $35 \cdot 5 \pm 1 \cdot 3$ & $35 \cdot 5 \pm 1 \cdot 1$ \\
\hline Transferrin $\mathrm{g} / \mathrm{l}(2 \cdot 0) \ddagger$ & $1 \cdot 80 \pm 1 \cdot 0$ & $1 \cdot 95 \pm 0 \cdot 1$ & $1 \cdot 85 \pm 0 \cdot 2 \S$ & $2 \cdot 30 \pm 0 \cdot 2 \S$ \\
\hline Serum pre-albumin mg/l (290) $\ddagger$ & $140 \pm 20 \|$ & $214 \pm 20 \|$ & $153 \pm 10 \pi$ & $244 \pm 20 \pi$ \\
\hline Lymphocyte count $\times 10^{6} /(1500) \ddagger$ & $1450 \pm 150$ & $1850 \pm 250$ & $1650 \pm 200$ & $1900 \pm 250$ \\
\hline Impaired skin tests (\% patients) & $72 \%$ & $44 \%$ & $81 \%$ & $67 \%$ \\
\hline
\end{tabular}

* Values in parentheses represent $60-90 \%$ of dult reference values. ${ }^{8}$

$\dagger$ MAMC $=$ MAC $-(\pi \times$ TSF $)$.

$\ddagger$ Lower limit of normal.

$\S \mathrm{p}<0.05$.

$\| \mathrm{p}<0.001$.

If $\mathrm{p}<0.001$.

(All values are means \pm SEM.) 
Table 6 Nitrogen balance data of patients fed more than seven days and with nitrogen losses less than 14.4 g/day

\begin{tabular}{|c|c|c|c|}
\hline & $\begin{array}{l}\text { Vivonex } \\
\text { group } \\
(n=25)\end{array}$ & $\begin{array}{l}\text { Clinifeed } \\
\text { group } \\
(n=21)\end{array}$ & $\begin{array}{l}\text { Significance } \\
\text { of } \\
\text { difference }\end{array}$ \\
\hline Intake of nitrogen (g) & $10.4 \pm 0.5$ & $10 \cdot 2 \pm 0 \cdot 4$ & NS \\
\hline Output of nitrogen ${ }^{5}(\mathrm{~g})$ & $9 \cdot 7 \pm 0 \cdot 7$ & $7 \cdot 7 \pm 0 \cdot 5$ & $p<0.05$ \\
\hline Nitrogen balance $(\mathrm{g})$ & $+0.64 \pm 0.8$ & $+2 \cdot 6 \pm 0 \cdot 6$ & NS \\
\hline $\begin{array}{l}\text { Mean duration of } \\
\text { feeding (days) }\end{array}$ & $16 \cdot 0 \pm 1 \cdot 6$ & $20 \cdot 3 \pm 2 \cdot 8$ & NS \\
\hline $\begin{array}{l}\text { Patients in positive } \\
\text { balance (no.) }\end{array}$ & $15(60 \%)$ & $17(81 \%)$ & NS \\
\hline $\begin{array}{l}\text { Urinary creatinine } \\
\text { excretion }(\mathrm{mmol} / 24 \mathrm{~h})\end{array}$ & $7 \cdot 5 \pm 0 \cdot 7$ & $7 \cdot 3 \pm 1 \cdot 0$ & NS \\
\hline $\begin{array}{l}\text { Urinary urea nitrogen }(\mathrm{g}) \text { : } \\
\text { creatinine excretion }(\mathrm{mmo}\end{array}$ & & & \\
\hline Days 1-3 & $\begin{array}{l}0.95 \pm 0.08 \\
p<0.02\end{array}$ & $0.96 \pm 0.1$ & NS \\
\hline $\begin{array}{l}\text { Day } 3 \text { onward } \\
\text { Patients infected (no.) }\end{array}$ & $\begin{array}{l}1 \cdot 23 \pm 0 \cdot 12 \\
10(40 \%)\end{array}$ & $\begin{array}{l}0 \cdot 83 \pm 0 \cdot 07 \\
12(57 \%)\end{array}$ & $\begin{array}{l}\mathrm{p}<0.01 \\
\text { NS }\end{array}$ \\
\hline
\end{tabular}

(All values are means \pm SEM.)

As shown in Table 6, significantly lower nitrogen excretion was found in the Clinifeed-fed patients, despite the fact that nitrogen and energy intake as well as initial assessment of muscle mass and the incidence of sepsis were similar in both groups. Despite the trial protocol - namely, to maintain nitrogen balance by appropriate adjustment of intake - only $60 \%$ of the Vivonex-fed patients and $81 \%$ of the Clinifeed-fed patients were maintained in overall positive balance throughout the study. In both groups, reduction of prescribed intakes because of intercurrent investigative and therapeutic manoeuvres requiring prior fasting, poor nasogastric tube compliance with delays in replacement, and failure to regulate infusion rates correctly combined to impede achievement of positive nitrogen balance.

Urinary urea nitrogen:urinary creatinine ratios from the third day onwards revealed that the metabolic status with regard to urea nitrogen excretion was significantly different in the two groups. Thus, more urea nitrogen was lost per mmol creatinine excreted during Vivonex therapy than during Clinifeed therapy $(\mathrm{p}<0.01)$, despite similar nitrogen intake and initial metabolic status.

\section{GASTROINTESTINAL SIDE EFFECTS}

The incidence of gastrointestinal side effects was evenly distributed between the two treatment groups, whether fed for less than seven days or more. Comparing the complete treatment groups, eight $(23.5 \%)$ on Vivonex and $11(30.6 \%)$ on Clinifeed developed diarrhoea, although none of these was withdrawn for this reason. All but one patient developing diarrhoea on Vivonex and two patients on Clinifeed were receiving concurrent antibiotic therapy. In one patient, laxatives were also being administered. Diarrhoea resolved within 24 hours of stopping treatment with antibiotics, but, when it was not possible to stop such treatment on clinical grounds, codeine phosphate $30-60 \mathrm{mg}$ thrice daily was sufficient to stop diarrhoea until such time as the antibiotics could be withdrawn.

Vomiting or regurgitation of gastric contents occurred in seven $(20.6 \%)$ of the Vivonex group and eight $(22.2 \%)$ of the Clinifeed group. In the Vivonex group, two comatose patients with head injuries and one with Guillain-Barré syndrome were withdrawn because of persistent regurgitation and, in one case, pulmonary aspiration. In half the cases of vomiting, a sudden bolus of feed, intercurrent urinary tract infection, a contaminated feed, or poor maintenance of the subdiaphragmatic position of the nasogastric tube could be implicated. A quantitative assessment of vomitus was possible in only a minority of patients.

\section{METABOLIC SIDE EFFECTS}

In the Clinifeed group an undiagnosed diabetic who became hyperglycaemic and ketotic was withdrawn. Two neurosurgical patients who developed severe hyponatraemia attributable to the inappropriate ADH syndrome and one patient who developed hypercalcaemia related to underlying neoplasia, all fed with Clinifeed, were also withdrawn. Potassium fell to below normal limits in $53 \%$ of patients on Vivonex and $47 \%$ on Clinifeed. Serum zinc levels fell below normal lower limits in only two patients on Vivonex and three on Clinifeed. No significant changes occurred in serum magnesium levels. Serum phosphate fell significantly during feeding with Vivonex $(1.11 \pm 0.7$ to $0.98 \pm 0.08 \mathrm{mmol} / \mathrm{l}, \mathrm{p}<0.05)$ by comparison with a rise in serum phosphate during Clinifeed administration (1.03 \pm 1.06 to $1.28 \pm 0.09$, $\mathrm{p}<0.05$ ), and levels below normal occurred more frequently on Vivonex $(p<0.05)$.

Red cell folate, serum $B_{12}$, and serum iron did not change significantly in either group. Serum folate, however, rose significantly in the Clinifeed group $(5 \cdot 2 \pm 1 \cdot 3$ to $7 \cdot 2 \pm 1 \cdot 4 \mu \mathrm{g} / 1, \mathrm{p}<0.05)$ but no such trend was detected in the Vivonex group $(3.6 \pm 0.8$ to $3 \cdot 6 \pm 0 \cdot 5$, NS).

\section{LIVER ENZYME CHANGES}

A rise of one or more of the three liver enzymes, alanine aminotransferase (ALT), aspartate aminotransferase (AST), and alkaline phosphatase (AP), above the upper limit of normal occurred in $35 \%$ of the Vivonex group and $41.7 \%$ of the Clinifeed group. In approximately one-third of those affected, an associated factor such as concurrent sepsis or 
antituberculous therapy could be implicated. Maximum levels reached during the study were as follows, with the upper limit of normal in parentheses: ALT, 141 (30) IU/l; AST, 170 (40) IU/l; AP, 156 (80) IU/l.

In none of the patients could a rise in serum bilirubin be attributed to enteral feeding alone. By the end of the study, the majority of abnormal results had returned to within normal limits and it was not necessary to withdraw any patient because of liver dysfunction.

\section{Discussion}

The results of this controlled study show that no major clinical differences existed between isonitrogenous isocaloric regimes of the "elemental diet' Vivonex HN and the polymeric diet Clinifeed 400 , when used as the sole means of nutritional support in a diagnostically heterogeneous group of patients with normal digestion and absorptive capacity. Both treatment groups were well matched and had moderate, but similar, degrees of nutritional depletion on entry to the study. In those fed for more than one week, the overall effect of nutritional support was to maintain rather than to improve skeletal muscle mass and fat reserves, which agrees well with the results of others. ${ }^{2}{ }^{3}$ This reflects both the high incidence of sepsis and immobility among our patients, as well as the number of patients not nutritionally depleted on entry to the study, but fed prophylactically.

Serum transferrin levels have been advocated as a means of assessing nutritional repletion with respect to protein synthesis. ${ }^{914}$ It is of interest, therefore, that a significant improvement in transferrin levels occurred only in the group of patients receiving the whole protein- and fat-containing diet, Clinifeed, a finding which is in keeping with the significantly lower urinary nitrogen excretion found in this treatment group compared with those receiving Vivonex, although the difference in nitrogen balance between the two groups did not achieve statistical significance. As similar inputs of nitrogen and energy were achieved in both treatment groups, the above findings do suggest that the nitrogen sparing effect of the whole protein-containing diet is superior to that of the elemental diet. Others have also found that positive nitrogen balance can be more readily achieved with polymeric diets but in those studies patients receiving elemental diets such as Vivonex did not achieve similar levels of intake as those on polymeric diets, mainly because of poor tolerance of the elemental regimes. ${ }^{3}$ Although much emphasis has been placed on the type of nitrogen source in enteral feeding, the role of fat may be of greater importance, as recent studies have demonstrated that fat appears to have a specific effect on repletion of lean body mass during parenteral nutrition of patients with moderate metabolic stress. ${ }^{15}$ It is, therefore, of interest to note that in this study the Clinifeed-based diet contained $25.1 \%$ of its non-protein energy in the form of fat compared with only $0.6 \%$ for the Vivonex-based diet. Indeed, the essential fatty acid content of Vivonex has recently been noted to be insufficient to prevent essential fatty acid deficiency during prolonged enteral nutrition. ${ }^{16}$

In the present study, both feeds were generally well tolerated, there being no significant difference in the incidence of either diarrhoea or vomiting, although three of $34(9 \%)$ Vivonex-fed patients were withdrawn because of the latter complication. As reported by others, ${ }^{717}$ antibiotics appeared to be the primary cause of diarrhoea in our patients, all of whom were fed continuously over a 24 hour period. There was no evidence to implicate either the hypertonicity of the elemental diet $(690 \mathrm{mOsm} / \mathrm{kg})$ or the lactose content $(19.5 \mathrm{~g} / \mathrm{l})$ of the polymeric diet as major factors in the aetiology of diarrhoea.

Despite the study protocol, which was designed to maintain nitrogen balance, many individual patients in each group remained in negative nitrogen balance throughout the study. This finding cannot be attributed entirely to the intrinsic properties of the feeds themselves, but represents more the practical difficulties encountered during enteral nutrition, such as persistent vomiting, or intercurrent investigations, or procedures requiring a 'nothing by mouth' regime. Moreover, the degree of negative nitrogen balance has probably been underestimated in those patients with diarrhoea, as the extra faecal nitrogen losses incurred were not assessed.

Metabolic disturbances occurred surprisingly frequently during the present study and generally reflected differences in formulation of the two diets. Hypokalaemia requiring potassium supplementation was found in nearly half the patients overall and was evenly distributed between the two treatment groups despite the higher potassium content of Clinifeed. The lower phosphate content of Vivonex, however, was reflected in the significantly greater incidence of hypophosphataemia in this group, and the failure of serum folate to rise from low normal values could be similarly attributed to the lower folate content. Liver enzyme rises occurred frequently in both groups. These changes, however, were not invariable as suggested by others, ${ }^{18}$ nor did we detect any rise above normal or serum bilirubin attributable to enteral feeding alone. The changes in liver enzymes were usually minor, returning to normal by the end of the study, 
whether normal or abnormal on entry to the study.

In view of the diagnostic heterogeneity of the patients in this study, it was not surprising that many of the rises in liver enzymes could be attributed to factors other than enteral feeding. While a number of factors have been noted to cause either cholestasis $^{19}$ or fatty infiltration ${ }^{18}$ during parenteral feeding, no clear pattern has evolved to explain the changes associated with enteral feeding. ${ }^{20}$ Neither the free amino acid nitrogen source of Vivonex, the whole protein source of Clinifeed, nor the relative differences in carbohydrate and fat contents can be implicated on the basis of results of the present study.

In conclusion, the two diets chosen for this study differed in a number of ways apart from their nitrogen sources. It is, therefore, not possible to draw firm comparisons between the efficacy of the nitrogen sources alone but the available evidence suggests that there is no justification for the use of expensive elemental diets such as Vivonex when gastrointestinal function is normal. The much cheaper polymeric diets such as Clinifeed would seem to be the more appropriate nutritional sources in such patients. Moreover, certain aspects of our data suggest that protein repletion occurred more effectively on the polymeric diet than the elemental diet. Further studies are required to assess the relative efficacies of elemental diets containing small peptides as the predominant nitrogen source, and also the role of polymeric diets when gastrointestinal function is moderately impaired.

The authors would like to thank the nursing staff of the Central Middlesex Hospital for their help and enthusiasm, and also $\mathrm{Dr} K \mathrm{~K}$ McCrae of the Department of Medical Statistics, Charing Cross Hospital, London.

\section{References}

1 Koretz RL, Mayer JH. Elemental diets - facts and fantasies. Gastroenterology 1980; 78: 393-410.

2 Fairfull-Smith R, Abunassar R, Freeman JB, Maroun JA. Rational use of elemental and non elemental diets in hospitalised patients. Ann Surg 1980; 192: 600-3.

3 Jones DG, Rich AJ, Wright PD, Johnston IDA. Comparison of proprietary elemental and whole- protein diets in unconscious patients with head injury. Br Med J 1980; 280: 1493-5.

4 Moriarty KJ, Hegarty JE, Fairclough PD, Clark ML, Dawson AM. Dietary nitrogen formulation: does it really matter? Gut 1981 ; 22: A430.

5 Lee HA, Hartley TF. A method of determining daily nitrogen requirements. Postgrad Med J 1973; 51: 441-5.

6 Kaminski MV. Enteral hyperalimentation. Surg Gynec Obstet 1976; 143: 12-6.

7 Allison SP, Walford S, Todorovic V, Elliot ET. Practical aspects of nutritional support. Res Clin Forums 1979; 1: 49-57.

8 Jelliffe DB. Assessment of the nutritional status of the community. Geneva: World Health Organisation, 1966.

9 Ingenbleek Y, Van des Shriek HG, De Nayer P, De Visscher $M$. Albumin, transferrin and thyroxine binding pre-albumin/retinol binding protein (TBPA/ RBP) complex in assessment of malnutrition. Clin Chim Acta 1975; 63: 61-7.

10 Meakins JL, Christov NV, Shizgal HM, McLean LD. Therapeutic approaches to energy in surgical patients. Ann Surg 1979; 190: 286-95.

11 Cuthbertson DP. Post-shock metabolic response. Lancet 1942; 1: 433-7.

12 Blackburn GL, Bistrian BR, Main BS, Schlamm HT, Smith MF. Nutritional and metabolic assessment of the hospitalised patient. J Parent Enteral Nutr 1977; 1: 11-22.

13 Collins JP, McCarthy ID, Hill GL. Assessment of protein nutrition in surgical patients - the value of anthropometrics. A J Clin Nutr 1979; 32: 1527-30.

14 Goode AW. The scientific basis of nutritional assessment. Br J Anaesth 1981; 53: 161-7.

15 McFie J, Smith RC, Hill GL. Glucose or fat as a non-protein energy source? A controlled clinical trial in gastroenterological patients requiring intravenous nutrition. Gastroenterology 1981; 80: 103-7.

16 Farthing MJG, Jarrett EB, Willias G, Crawford MA. Essential fatty acid deficiency after prolonged treatment with elemental diet. Lancet 1980; 2: 1088-9.

17 Broom J, Jones K. Causes and prevention of diarrhoea in patients receiving enteral nutritional support. $J$ Human Nutr 1981; 35: 123-7.

18 Skidmore FD, Tweedle DEF, Gleave EN, Gowland E, Knass DA. Abnormal liver function during nutritional support in post-operative cancer patients. Ann R Coll Surg Engl 1979; 61: 184-8.

19 Sitges-Creus A, Canadas E, Vilar L. Cholestatic jaundice during parenteral alimentation in adults. In: Johnston IDA, ed. Advances in parenteral nutrition. Lancaster: MTP Press, 1977: 461-72.

20 Tweedle DEF, Skidmore FD, Gleave EN, Knass DA, Gowland E. Nutritional support for patients undergoing surgery for cancer of the head and neck. Res Clin Forums 1979; 1: 59-65. 